\title{
Anthropogenic soils and land use patterns in relation to small mammal and flea abundance in plague endemic area of Western Usambara Mountains, Tanzania
}

DIDAS N. KIMARO ${ }^{*}$, BALTHAZAR M. MSANYA ${ }^{2}$, JOEL MELIYO ${ }^{2}$, PROCHES HIERONIMO ${ }^{1}$, SIBAWAY MWANGO ${ }^{2}$, NGANGA I. KIHUPI', HUBERT GULINCK ${ }^{3}$ and JOZEF A. DECKERS ${ }^{3}$

'Department of Agricultural Engineering and Land Planning, Sokoine University of Agriculture, P.O. Box 3003, Morogoro, Tanzania

${ }^{2}$ Department of Soil Science, Sokoine University of Agriculture, P.O. Box 3008, Morogoro, Tanzania

${ }^{3}$ Department of Earth \& Environmental Sciences, University of Leuven, Celestijnenlaan 200 E, B-3001 Heverlee, Belgium

\begin{abstract}
Heterogeneity in the landscapes of West Usambara Mountains on land use and human activities has been reported. However, the interface of land use patterns and human modified soils with small mammal and flea abundance for possible explanation of plague has not been explored. This study was carried out to determine the link between anthropogenic soils and land use patterns on small mammal and flea abundance and the occurrence of reported plague in the Western Usambara Mountains in Tanzania. Standard soil survey methods were used to identify and describe soils and land use patterns on lower slopes and valley bottoms on which the surrounding villages are reported to have high and medium plague frequencies. The identified soils were characterised in terms of their morphological and physico-chemical properties and classified according to FAO-World Reference Base for Soil Resources. Small mammals were trapped on the same landscape positions and identified to genus/species level. Fleas were removed from the trapped small mammals, counted and identified to species level. In total 57 small mammals were captured from which 32 fleas were collected. Results show that human settlements and mixed cultivation on lower slopes and continuous vegetable cropping in the valley bottoms are dominant land use types. Intensive use of forest soils, manuring and irrigation on farms in the studied landscapes have contributed to the development of uniquely human modified soils namely Hortic Anthrosols in the lower slopes and Plaggic Irragric Hortic Anthrosols in valley bottoms. The identified anthropogenic soils and land use patterns are associated with high abundance of small mammals (Mastomys natalensis) and flea species (Xenopsylla brasiliensis and Dinopsyllus lypusus). This phenomenon is vividly apparent in the villages with medium to high plague frequencies. The study suggests that plague surveillance programmes should consider the existing relationship between anthropogenic soils, land use patterns, small mammal and flea abundance.
\end{abstract}

Keywords: anthropogenic soils, land use, small mammals, fleas, plague, Tanzania

\section{Introduction}

Anthropogenic soils are surface soil layers (horizons) found wherever people have practised agriculture for a long time. According to the World Reference Base for Soil Resources, such soil layers include black or brown human-induced mineral surface soils that have been produced by long-continued manuring (Plaggic); mineral surface soils that have developed through addition of earthy manures, compost, beach sands or mud over a long period of time (Terric); deep cultivation, intensive fertilization and/or long continued application of human and animal wastes and other organic residues (e.g. manures, kitchen refuse, compost and night soil) (Hortic). Others include soil surface layers associated with wet cultivation and which occur below the puddle layer and the plough pan (Hydragric); continuous application of irrigation water with substantial amounts of sediments (Irragric); soil surface layer that comprises a puddled layer and a plough pan (Anthraquic) and a moderately thick, dark coloured soil surface layer associated with old arable lands that have been cultivated for centuries including ploughing, liming and fertilization (Anthric) (WRB, 2006).

Studies show that most of the Anthrosols with plaggic horizons are most common in Northwest Europe and together with Anthrosols having a terric horizon they cover more than 500,000 ha (WRB, 2006; Meuser, 2010). Anthrosols with irragric horizons are found in dry regions

Correspondence: Didas N. Kimaro; E-mail: didas_kimaro@yahoo.com 
with intensive irrigation such as in desert regions and in parts of India (Bor, 2010). Anthraquic horizon is common in China and in parts of South and Southeast Asia including (Kwan-Cheol et al., 2011). Anthrosols with hortic horizons are found all over the world where humans have fertilized the soil with household wastes and manure and are most common in the Amazon Region of Brazil (Glaser et al., 2001; Glaser, 2007)). It is apparent that most of these soils have been studied in Europe, Asia and South America. Very little is known about such soils in Africa which has a very long history of cultivation practices in the spectacular landscapes including mountains with different history of origin, plateaus, plains and valley bottoms.

In the Usambara Mountains, long history of vegetable cultivation in the valley bottoms, and soil erosion control practices, (bench terraces, miraba) have been practiced by farmers for over 300 years (Msita et al., 2011). Miraba is an indigenous land management practice with grass strips surrounding crop fields in a rectangular shape in the West Usambara Mountains, Tanzania (Msita et al., 2012). For many years, application of forest soils mined from the natural forest and forest plantation, manure, irrigation and drainage is common in the Usambara Mountains (Hubeau, 2010). Interaction of these land uses and human activities in the landscapes reported with plague history has resulted into human modified soils. It can be hypothesised here that agricultural intensification, use of irrigation and organic fertilizers with the associated habitat modification, are likely to affect the opportunities for breeding by hosts and vectors of diseases (Kuo et al., 2012). However, in the West Usambara Mountains in Tanzania, which are reported with history of plague incidence, studies that link the interface between land use and the human modified soils in the landscape are lacking. Underlying the heterogeneity of the landscape of West Usambara Mountains in terms of land use and human activities, this study therefore attempted to explore the possible interface of land use patterns and human modified soils with small mammal and flea abundance at farm scale and within a geographic scope for possible contribution to the overall landscape-plague ecology.

\section{Materials and methods}

\section{Study area}

The study was conducted in West Usambara Mountains, Lushoto District in Tanzania, in an area selected between Universal Transverse Mercator (UTM) coordinates $412500 \mathrm{~m} \mathrm{E}$ and $423000 \mathrm{~m} \mathrm{E}$ and between $9478500 \mathrm{~m} \mathrm{~N}$ and $9486000 \mathrm{~m} \mathrm{~N}$ Zone 37M (Figure 1). The altitude ranges from 1020 to $2050 \mathrm{~m}$, and slope angle from $1^{\circ}$ to $60^{\circ}$. The area has a bimodal rainfall pattern with mean annual rainfall ranging from 500 to $1000 \mathrm{~mm}$. The study area shows large differences in relief dissection and intensity, vegetation and land use patterns, and human activities. Land use is characterised by mixed rainfed farming (on slopes), irrigated agriculture (mainly in the valley bottoms), livestock keeping and off farm activities (Msita et al., 2010).

Previous research on small mammals (rodents), fleas and plague (Kilonzo et al., 1997; Davis et al., 2006; Kamugisha et al., 2007; Laudisoit et al., 2007, 2009a, b; Neerinckx et al., 2010) allowed defining the study area into landscape units that reflects a geographical gradient into different levels of plague incidence. These authors concurred in distinguishing high and medium plague incidence zones. Within this gradient two representative landscapes were selected differing in terms of (i) the frequency of plague (ii) diversity in land use and associated human activities and (iii) landform characteristics (relief intensity and landscape position). The selected landscapes are named Gologolo (high plague frequency) and Lukozi (medium plague frequency), after the name of their most important settlement. The Gologolo landscape (high reported plague frequency), is made up of villages where on average plague occurred in $>3$ years per decade and Lukozi landscape (medium reported plague frequency), is made up of villages where the disease occurred in 2-3 years per decade (Laudisoit et al., 2007). On the basis of these criteria, two landscape positions namely lower slopes and valley bottoms from each landscape were selected as sample areas for the current study. Sub-villages with records on historical plague 
incidence around each landscape position were also identified for collecting data on plague frequency.

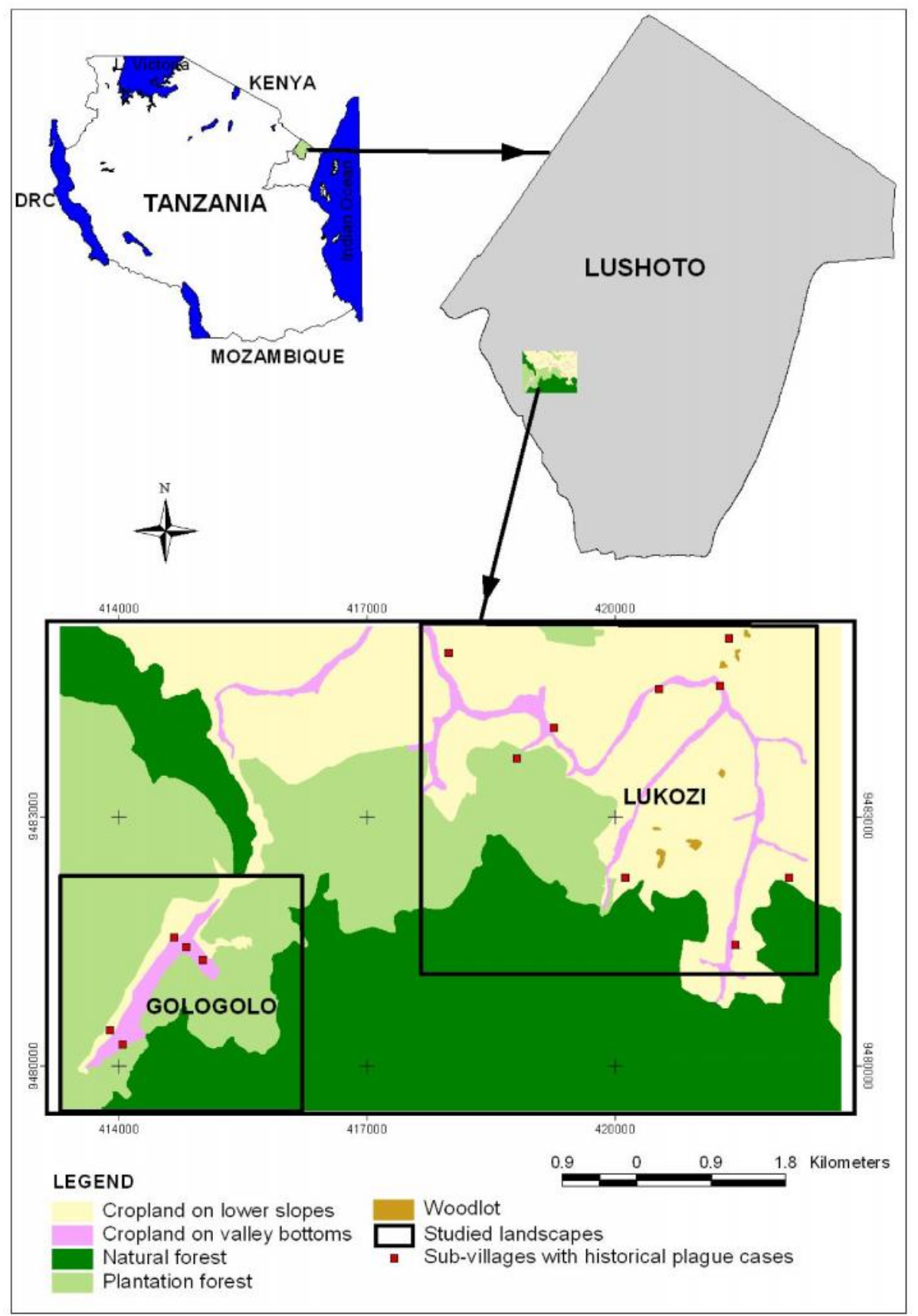

Figure 1: Background map showing major land cover types of the two studied landscapes in the study area

Identification of land use patterns and human modified soils

At each landscape position (lower slopes and valley bottoms) various visible indicators of land use were identified and described. The identified land use patterns were described in terms of their characteristic land cover patterns as seen in the field and discriminated by land management practices including type of cover and / or crops, cropping pattern, fertilisation and irrigation. Human activities suggestive to contribute to the development of human modified soils were also established through field observations and information from key informants. Such 
human activities include collection of forest soils from natural forest, application of farm yard manure, irrigation and terracing.

Likewise, systematic free survey at semi-detailed scale $(1: 50,000)$ was carried out on the same landscape positions to establish patterns of soils (Dent \& Young, 1981). Transects were used as sites for soil observation and sampling. Observations were done at an intensity of 8 observations per $\mathrm{km}^{2}$ following procedures outlined by Dent $\&$ Young (1981). At each observation site, data on soil morphological characteristics and terrain attributes such as elevation and slope gradient were studied. Land use characteristics were also described to supplement earlier descriptions. Soils were described using soil mini-pits to a depth of $50 \mathrm{~cm}$ and auguring to $120 \mathrm{~cm}$ or to limiting layer. Correlation of the soil auger observations with terrain characteristics such as slope gradient and land use enabled soils which are similar in characteristics and in arrangements of soil horizons to be identified. In this way four soil units associated with specific land use patterns and land management practices were identified.

Based on the information obtained from field observations for each identified soil unit, sites for representative soil profile pits were identified. Geographical Positioning System (GPS) was used to determine the geographical locations of the sites. Soil profile pits were dug to a depth of $2 \mathrm{~m}$ or to a limiting layer. A total of four fully geo-referenced soil profile pits representing the human modified soils (anthropogenic soils) were studied and described according to FAO Guidelines for Soil Description (FAO, 2006). Soil profile morphological characteristics studied included soil colour, texture, consistence, structure, porosity, effective depth, presence or absence of artefacts, spade marks, buried humus layers, cutans, mottles, concretions and type of primary minerals and rock fragment. Soil colour was determined by Munsell soil colour charts (Munsell Colour Co., 2000). After the description of the soils, in each soil profile pit, a total of 16 bulk soil samples were taken from designated natural horizon from each georeferenced soil profile pit for physical and chemical analysis in the laboratory.

The collected soil samples were analysed in the laboratory for texture, $\mathrm{pH}_{\text {water }}$, exchangeable cation (EC), total nitrogen (TN), organic carbon (OC), cation exchange capacity (CEC), and bases following the handbook by Moberg (2000). Using field and laboratory data, the soils were classified to Tier 2 of the FAO World Reference Base (WRB, 2006).

\section{Identification of small mammals and fleas}

Trapping of small mammals was done on the lower slopes and valley bottoms of the Gologolo and Lukozi landscapes where the anthropogenic soils were identified. Three sites (two on the lower slopes and one in the valley bottoms) and four sites (two on the lower slopes and one in the valley bottoms) were selected for trapping of small mammals at Gologolo and Lukozi landscapes, respectively. Small mammals were captured using Sherman LFA live traps $(7.5 \times 9.0 \mathrm{x}$ $23 \mathrm{~cm}$; HB Sherman Traps, Tallahassee, USA) baited with peanut butter and maize flower. A total of 49 Sherman live traps spaced $10 \mathrm{~m}$ apart were set in a grid per trapping site (quadrant) and per trapping session. Each trapping session lasted for 3 nights. Each trap was inspected every morning and traps with captured animals were replaced by empty traps. Individual small mammals were identified to genus or species level where possible (Eisen et al., 2012) and carefully combed for fleas. Fleas were stored in $70 \%$ ethanol in individual vials for each host specimen and transported to the Department of Biology of the University of Antwerp (Belgium) for subsequent identification to species level (Laudisoit et al., 2009a). In total 57 animals were captured from which 32 fleas were collected.

\section{Data on plague frequency}

Plague frequency (PF) data were obtained from literature (Laudisoit et al., 2007) for 13 villages identified within the studied landscapes of Gologolo and Lukozi. The majority of the villages in these landscapes had historical recorded plague frequency of $\geq 0.2$ and were considered in this study. According to Laudisoit et al. (2007) plague frequency (PF) $<0.2$ is rated as low while $>0.3$ is 
rated as high. In total four and nine sub-villages with PF $>0.2$ were identified at Gologolo and Lukozi landscapes, respectively.

\section{Data analysis}

The land use information was based on field descriptions and land use classification system following FAO Guidelines for Soil Description (FAO, 2006). The different locations of the activities were also put together in tables and converted into layers of information. These layers of information were used to establish relationships between small mammal and flea abundance and plague frequency with the identified anthropogenic soils and land use patterns.

Percentage of animals captured was used to establish the abundance of small mammals at each landscape position with the identified anthropogenic soil types and land use patterns. From the collected fleas, flea indices were calculated per landscape position with the identified anthropogenic soil type and a given land sue pattern. Flea index was calculated as the total number of fleas per total number of captured mammals (Laudisoit et al., 2009a) and it was used as a measure of flea abundance.

\section{Ethical considerations}

This study received approval from Directorate of Research and Post-Graduate Studies of Sokoine University of Agriculture, Tanzania and Flemish Inter-University Council (VLIR-UOS) of Belgium.

\section{Results}

\section{Land use patterns and associated human activities}

The land use of the studied landscapes consisted of three main categories: settlements, cultivation and forest plantations. On the lower slopes of the landscapes, the typical land use was rainfed agriculture with Irish potato, beans, maize, cassava, various fruits, banana and assorted trees and maize cultivation and/or mixed agroforestry. Also scattered trees were planted as hedges along crop field borders or as mixed farming (agroforestry). In this landscape most settlements were concentrated on the lower slopes and therefore major human activities were domestic activities around the settlements and continuous farming on lower slopes including terracing.

In the valley bottoms, the dominant land use was irrigated agriculture. Within the valley, small and narrow streams were dug. These streams served two functions namely, drainage of the crop fields during the rainy season and irrigation of the crop fields during the dry season. The irrigation practices were carried out in different ways such as watering each plant individually by means of a bucket or a watering can, or irrigating by using a hose pipe to wet the entire plot. Furrow irrigation was also practiced. In the valleys bottoms the dominant crops grown were mostly vegetables, including cabbage, carrots and tomatoes. The crops were mostly planted as mono-crop but in some places intercropping was done. Intensive, mixed irrigated agriculture dominantly with vegetable cultivation, drainage, and addition of forest soils and manure were common human activities in this landscape position.

Other human activities common in the lower slopes and valley bottoms of Lukozi landscape were indigenous soil and water conservation measures popularly known as miraba (Msita et al., 2010, 2013). Miraba is an indigenous land management practice with grass strips surrounding crop fields. The miraba were located more on lower slopes than in the valley bottoms. The location and size of miraba depended mainly on landform where miraba are located, slope length and field plot size owned by the farmer (Msita, 2013). During field survey, it was observed that generally bigger size miraba were located in the valley bottoms to control flood wash, and small ones were on the slopes. 
Table 1: Land use patterns and associated human activities in the studied landscapes

\begin{tabular}{|c|c|c|c|c|c|c|}
\hline Landscape & $\begin{array}{l}\text { Landscape } \\
\text { position }\end{array}$ & $\begin{array}{l}\text { Altitude } \\
(\mathrm{ml})\end{array}$ & $\begin{array}{l}\text { Slope } \\
\text { gradient (\%) }\end{array}$ & $\begin{array}{l}\text { Soil erosion } \\
\text { features }\end{array}$ & Land use pattern & $\begin{array}{l}\text { Anthropogenic } \\
\text { activities }\end{array}$ \\
\hline \multirow[t]{2}{*}{ Gologolo } & $\begin{array}{l}\text { Lower } \\
\text { slopes }\end{array}$ & 1851 & 36 & $\begin{array}{l}\text { Rill, interrill } \\
\text { and gully }\end{array}$ & $\begin{array}{l}\text { Settlements, Irish } \\
\text { potato, beans } \\
\text { and maize } \\
\text { cultivation, forest } \\
\text { plantations }\end{array}$ & $\begin{array}{l}\text { Application of } \\
\text { household } \\
\text { waste on farms } \\
\text { and terracing }\end{array}$ \\
\hline & $\begin{array}{l}\text { Valley } \\
\text { bottoms }\end{array}$ & 1831 & 1 & Deposition & $\begin{array}{l}\text { Intensive } \\
\text { irrigated } \\
\text { vegetable } \\
\text { cultivation } \\
\text { (cabbage, } \\
\text { carrots, } \\
\text { tomatoes, and } \\
\text { Irish potato) }\end{array}$ & $\begin{array}{l}\text { Intensive } \\
\text { irrigation, } \\
\text { drainage, } \\
\text { farming, } \\
\text { addition of } \\
\text { forest soils and } \\
\text { manure on } \\
\text { farms }\end{array}$ \\
\hline \multirow[t]{2}{*}{ Lukozi } & $\begin{array}{l}\text { Lower } \\
\text { slopes }\end{array}$ & 1770 & 32 & $\begin{array}{l}\text { Rill, interrill } \\
\text { and gully }\end{array}$ & $\begin{array}{l}\text { Settlements and } \\
\text { cultivation of } \\
\text { maize, beans, } \\
\text { Irish potato, } \\
\text { wheat, and fruits, } \\
\text { terraces and } \\
\text { intensive miraba } \\
\text { farming }\end{array}$ & $\begin{array}{l}\text { Application of } \\
\text { household } \\
\text { waste on farms, } \\
\text { terracing and } \\
\text { intensive miraba } \\
\text { farming }\end{array}$ \\
\hline & $\begin{array}{l}\text { Valley } \\
\text { bottoms }\end{array}$ & 1763 & 2 & Deposition & $\begin{array}{l}\text { Intensive } \\
\text { irrigated } \\
\text { vegetable } \\
\text { cultivation } \\
\text { (cabbage, } \\
\text { carrots, } \\
\text { tomatoes, and } \\
\text { Irish potato) and } \\
\text { sketchy miraba } \\
\text { farming }\end{array}$ & $\begin{array}{l}\text { Intensive } \\
\text { irrigation, } \\
\text { drainage, } \\
\text { farming, } \\
\text { addition of } \\
\text { forest soil and } \\
\text { manure on } \\
\text { farms and } \\
\text { sketchy miraba } \\
\text { farming }\end{array}$ \\
\hline
\end{tabular}

\section{Anthropogenic soils and their associated salient features}

Salient features of the identified anthropogenic soils in the studied landscapes are presented in Table 2. The anthropogenic soils of Gologolo landscape on lower slopes have thick surface layer (horizon) of $30 \mathrm{~cm}$ with high organic carbon (> $6 \%$ ) and sandy clay texture. According to WRB (2006) these soils classify as Hortic Anthrosols (Epieutric, Clayic). Those of Lukozi landscape on the same slope position (lower slope) are very deep, well drained sandy clay loam with buried original soil surface (buried humic surface layer). These soils classifies as Hortic Plaggic Anthrosols (Hypereutric, Clayic.

The soils of the valley bottoms in both landscapes are sand clay loam, very deep, poorly to imperfectly drained with thick black topsoil $(>30 \mathrm{~cm})$ and high organic carbon $(>6 \%)$. These soils classify as Hortic, Irragric, Plaggic and Hortic Plaggic Irragric Anthrosols (Hypereutric, Epiclayic). According to ratings by Baize (1993), the Anthrosols of the valley bottoms of the studied landscapes have high fertility characterised by high base saturation (>50\%), high topsoil available phosphorus (>10 mgP/kg soil) and high top soil CEC (> $35 \mathrm{cmol}(+) / \mathrm{kg}$ soil (Table 3$)$. 
Table 2: The identified anthropogenic soils and their associated salient features

\begin{tabular}{|c|c|c|c|c|c|c|}
\hline Landscape & $\begin{array}{l}\text { Landscape } \\
\text { position }\end{array}$ & $\begin{array}{l}\text { Anthropogenic } \\
\text { indicators }\end{array}$ & $\begin{array}{l}\text { Morphological } \\
\text { properties }\end{array}$ & $\begin{array}{l}\text { Diagnostic } \\
\text { horizons }\end{array}$ & Qualifiers & $\begin{array}{l}\text { Tier } 2 \text { WRB - } \\
\text { RSG name }\end{array}$ \\
\hline \multirow[t]{2}{*}{ Gologolo } & Lower slope & $\begin{array}{l}\text { Thick topsoil } \\
(30 \mathrm{~cm}) ; \text { high } \\
\text { OM content (> } \\
6 \%)\end{array}$ & $\begin{array}{l}\text { vd, wd, very } \\
\text { thick topsoil, } \\
\text { vdb SC topsoil }\end{array}$ & Hortic & $\begin{array}{l}\text { Hortic } \\
\text { (Epieutric, } \\
\text { Clayic) }\end{array}$ & $\begin{array}{l}\text { Hortic } \\
\text { Anthrosols } \\
\text { (Epieutric, } \\
\text { Clayic) }\end{array}$ \\
\hline & $\begin{array}{l}\text { Valley } \\
\text { bottoms }\end{array}$ & $\begin{array}{l}\text { Thick topsoil } \\
(35 \mathrm{~cm}) \text {; high } \\
\text { OM content (> } \\
6 \%) ; \text { use of } \\
\text { forest soil and } \\
\text { FYM }\end{array}$ & $\begin{array}{l}\text { vd, poorly to } \\
\text { imperfectly } \\
\text { drained, black } \\
\text { topsoil }\end{array}$ & $\begin{array}{l}\text { Hortic, } \\
\text { Irragric, } \\
\text { Plaggic }\end{array}$ & $\begin{array}{l}\text { Irragric, } \\
\text { Plaggic, Hortic } \\
\text { (Hypereutric, } \\
\text { Epiclayic) }\end{array}$ & $\begin{array}{l}\text { Hortic Plaggic } \\
\text { Irragric } \\
\text { Anthrosols } \\
\text { (Hypereutric, } \\
\text { Epiclayic) }\end{array}$ \\
\hline \multirow[t]{2}{*}{ Lukozi } & Lower slope & $\begin{array}{l}\text { Buried topsoil } \\
\text { due to } \\
\text { terracing; } \\
\text { Miraba }^{*}\end{array}$ & $\begin{array}{l}\text { vd, wd, vdb } \\
\text { colour SCL } \\
\text { topsoil }\end{array}$ & $\begin{array}{l}\text { Hortic, } \\
\text { Plaggic }\end{array}$ & $\begin{array}{l}\text { Plaggic, Hortic } \\
\text { (Hypereutric, } \\
\text { Clayic) }\end{array}$ & $\begin{array}{l}\text { Hortic Plaggic } \\
\text { Anthrosols } \\
\text { (Hypereutric, } \\
\text { Clayic) }\end{array}$ \\
\hline & $\begin{array}{l}\text { Valley } \\
\text { bottoms }\end{array}$ & $\begin{array}{l}\text { Thick topsoil } \\
(33 \mathrm{~cm}) ; \text { high } \\
\text { OM content (> } \\
6 \%) ; \text { use of } \\
\text { forest soil and } \\
\text { FYM }\end{array}$ & $\begin{array}{l}\text { vd, poorly to } \\
\text { imperfectly } \\
\text { drained, black } \\
\text { topsoil }\end{array}$ & $\begin{array}{l}\text { Hortic, } \\
\text { Irragric, } \\
\text { Plaggic }\end{array}$ & $\begin{array}{l}\text { Irragric, } \\
\text { Plaggic, Hortic } \\
\text { (Hypereutric, } \\
\text { Epiclayic) }\end{array}$ & $\begin{array}{l}\text { Hortic Plaggic, } \\
\text { Irragric } \\
\text { Anthrosols } \\
\text { (Hypereutric, } \\
\text { Epiclayic) }\end{array}$ \\
\hline
\end{tabular}

Key: OM = organic matter; FYM farmyard manure; WRB = World Reference Base; RSG = Reference Soil Group; SC = Sand clay; SCL =Sandy clay loam; vd = very deep; $w d=$ well drained; vdb = very dark brown

${ }^{*}$ Miraba $=$ an indigenous land management practice with grass strips surrounding crop fields

Table 3: Physico-chemical soil properties of an Anthrosols in the valley bottom of Gologolo landscape (high plague incidence)

\begin{tabular}{|c|c|c|c|}
\hline Horizon & Ap & $\mathrm{Cg}$ & $2 \mathrm{Cg}$ \\
\hline Depth (cm) & $0-33$ & $33-75$ & $75-100$ \\
\hline Clay (\%) & 31 & 56 & 47 \\
\hline Silt (\%) & 20 & 22 & 8 \\
\hline Sand (\%) & 49 & 22 & 45 \\
\hline Texture class & $\mathrm{SCL}$ & $\mathrm{C}$ & $\mathrm{SC}$ \\
\hline $\mathrm{pH} \mathrm{H} \mathrm{O}_{2} \mathrm{O}: 2.5$ & 6.2 & 6.3 & 5.6 \\
\hline Organic C (\%) & 6.29 & 4.58 & 1.11 \\
\hline Organic matter (\%) & 11 & 8 & 2 \\
\hline Total N (\%) & 0.49 & 0.39 & 0.09 \\
\hline Avail. P Brayl (mg/kg) & 21.73 & 4.85 & 5.28 \\
\hline $\mathrm{CEC} \mathrm{NH}{ }_{4} \mathrm{OAC}_{\text {soil }}(\mathrm{cmol}(+) / \mathrm{kg})$ & $35 \cdot 99$ & 33.16 & 14.77 \\
\hline $\mathrm{CEC}_{\text {Clay }}(\mathrm{cmol}(+) / \mathrm{kg})$ & $117 \cdot 3$ & 59.2 & 31.3 \\
\hline Exch. Ca $(\mathrm{cmol}(+) / \mathrm{kg})$ & 19.02 & 14.20 & 4.15 \\
\hline Exch. Mg (cmol(+)/kg) & 6.65 & 6.68 & 3.10 \\
\hline Exch. K (cmol(+)/kg) & 0.39 & 0.10 & 0.02 \\
\hline Exch. $\mathrm{Na}(\mathrm{cmol}(+) / \mathrm{kg})$ & 0.60 & 0.72 & 0.48 \\
\hline Base saturation (\%) & 74 & 65 & 52 \\
\hline
\end{tabular}


Small mammals and fleas' abundance with respect to land use patterns and the identified anthropogenic soils

Results show that the abundance of small mammal and flea species is relatively high in the studied landscape positions with specific land use patterns and anthropogenic soils. The species relative abundance shows that Mastomys natalensis and Mus sp. were the dominant rodent species on landscapes with anthropogenic soils (Table 4). Results further show that M. natalensis, was also found in relatively high abundance in the Lukozi landscape characterised by intensive cultivation with terracing, miraba farming and anthropogenic soils associated with intensive application of forest soils and farm yard manure (Tables 1 and 2). The abundance of $M$. natalensis, accounted for $93 \%$ of all the captured animals in the studied landscapes with anthropogenic soils. Most fleas were collected in the Lukozi landscape corresponding also to the abundance of small mammals captured in this landscape. A total of 34 rodent fleas belonging to 8 identified species were collected. The two species namely Xenopsylla brasiliensis and Dinopsyllus lypusus, which make up a total of 21 fleas ( $61 \%$ ) of the total collection, were dominant in the two studied landscapes (Table 4).

Table 4: The identified anthropogenic soils and the associated small mammals and fleas specie abundance

\begin{tabular}{|c|c|c|c|c|c|c|}
\hline Landscape & $\begin{array}{l}\text { Landscape Position } \\
\text { (Anthropogenic } \\
\text { soils) }\end{array}$ & $\begin{array}{l}\text { Small mammals } \\
\text { species }\end{array}$ & $\begin{array}{l}\text { Rodent } \\
\text { abundance }\end{array}$ & Fleas species & $\begin{array}{l}\text { Absolute } \\
\text { flea } \\
\text { abundance }\end{array}$ & $\begin{array}{l}\text { Flea } \\
\text { index }\end{array}$ \\
\hline \multirow[t]{6}{*}{ Gologolo } & Lower slopes (Hortic & Mastomys natalensis & $6(10.5 \%)$ & Xenopsylla brasiliensis & $1(2.9 \%)$ & 0.57 \\
\hline & $\begin{array}{l}\text { Anthrosols } \\
\text { (Epieutric, Clayic)) }\end{array}$ & Mus sp & $1(1.8 \%)$ & Dinopsyllus lypusus & $4(12.0 \%)$ & \\
\hline & $\frac{\text { Valley bottoms }}{\text { (Hortic Plaggic }}$ & Mastomys natalensis & $8(14.0 \%)$ & $\begin{array}{l}\text { Ctenophthalmus calceatus } \\
\text { cabirus }\end{array}$ & $2(5.9 \%)$ & 1.183 \\
\hline & Irragric Anthrosols & & & Dinopsyllus lypusus & $6(17.6 \%)$ & \\
\hline & (Hypereutric, & & & Nosopsyllus incisus & $1(2.9 \%)$ & \\
\hline & Epiclayic)) & & & Ctenophthalmus sp & $1(2.9 \%)$ & \\
\hline \multirow[t]{9}{*}{ Lukozi } & Lower slopes (Hortic & Mastomys natalensis & $17(29.8 \%)$ & Xenopsylla brasiliensis & $3(8.8 \%)$ & 0.20 \\
\hline & Plaggic Anthrosols & Mus sp & $1(1.8 \%)$ & Dinopsyllus lypusus & $2(5.9 \%)$ & \\
\hline & (Hypereutric, Clayic)) & & & Dinopsyllus grypuruss & $1(2.9 \%)$ & \\
\hline & & & & Ctenophthalmus sp & $1(2.9 \%)$ & \\
\hline & Valley bottoms & Mastomys natalensis & $22(38.6 \%)$ & Xenopsylla brasiliensis & $2(5.9 \%)$ & 0.55 \\
\hline & (Hortic Plaggic, & Mus sp & $2(3.5 \%)$ & Dinopsyllus lypusus & $3(8.8 \%)$ & \\
\hline & $\begin{array}{l}\text { Irragric Anthrosols } \\
\text { (Hypereutric, }\end{array}$ & & & $\begin{array}{l}\text { Ctenophthalmus } \\
\text { leptodactylus }\end{array}$ & $2(5.9 \%)$ & \\
\hline & Epiclayic)) & & & $\begin{array}{l}\text { Ctenophthalmus calceatus } \\
\text { cabirus }\end{array}$ & $2(5.9 \%)$ & \\
\hline & & & & $\begin{array}{l}\text { Leptopsylla aethiopica } \\
\text { aethiopica }\end{array}$ & $3(8.8 \%)$ & \\
\hline Total & & & 57 & & 34 & \\
\hline
\end{tabular}

Plague frequency associated with anthropogenic soils, land use, small mammals and flea abundance

Association of plague frequency with anthropogenic soils, land use patterns, small mammals and fleas' abundance is presented in Table 5. Villages with high plague frequency were observed in Gologolo landscape (Madina and Majengo with PF values $>0.40$ ). Plague frequency for the villages in the Lukozi landscape are relatively lower (PF < 0.33) when compared to Gologolo landscape. Although the number of small mammals in Lukozi landscape is higher than in Gologolo, flea indices portray the opposite picture being higher in Gologolo than Lukozi.

\section{Discussion}

It is apparent that the interface between land use pattern and the identified anthropogenic soils is high abundance of small mammals and fleas. Previous studies indicated high abundance of small mammals in the studied landscapes but Gologolo having relatively higher number than 
Lukozi landscape when not considering other interfaces like anthropogenic soils (Makundi et al., 2003). The most common small mammals that were reported in these landscapes include Mastomys natalensis, Lophuromys sp and Praomys sp (Makundi et al., 2007; Laudisoit, 2009). These study areas with anthropogenic soils were dominated by $M$. natalensis. Other studies reported further that Gologolo landscape had greater number of Mastomys natalensis and Lophuromys sp than Lukozi landscape which is close to Magamba (Laudisoit et al., 2009b). However, when anthropogenic soils and land use are considered, it appears that $M$. natalensis and Mus sp are the dominant species associated with these soils and the related land use patterns.

Table 5: Association between anthropogenic soils, land use patterns and small mammal and flea abundance with reported historical plague frequency (PF)

\begin{tabular}{|c|c|c|c|c|c|c|}
\hline Landscape & $\begin{array}{l}\text { Landscape } \\
\text { Position } \\
\text { (Anthropogenic } \\
\text { soils) }\end{array}$ & $\begin{array}{l}\text { Land use } \\
\text { patterns }\end{array}$ & Sub-village & $\begin{array}{l}\text { Reported } \\
\text { PF }\end{array}$ & $\begin{array}{l}\text { Rodent } \\
\text { abundance }\end{array}$ & $\begin{array}{l}\text { Flea } \\
\text { abundance }\end{array}$ \\
\hline \multirow[t]{2}{*}{ Gologolo } & $\begin{array}{l}\text { Lower slopes } \\
\text { (Hortic Anthrosols } \\
\text { (Epieutric, Clayic)) }\end{array}$ & $\begin{array}{l}\text { Settlements, Irish } \\
\text { potato, beans } \\
\text { and maize } \\
\text { cultivation, forest } \\
\text { plantations }\end{array}$ & Madina & 0.40 & $7(12 \%)$ & 0.57 \\
\hline & $\begin{array}{l}\text { Valley bottoms } \\
\text { (Hortic Plaggic } \\
\text { Irragric Anthrosols } \\
\text { (Hypereutric, } \\
\text { Epiclayic)) }\end{array}$ & $\begin{array}{l}\text { Intensive } \\
\text { irrigated } \\
\text { vegetable } \\
\text { cultivation } \\
\text { (cabbage, } \\
\text { carrots, } \\
\text { tomatoes, and } \\
\text { Irish potato) }\end{array}$ & $\begin{array}{l}\text { Kazandabweni } \\
\text { Midamba } \\
\text { Majengo }\end{array}$ & $\begin{array}{l}0.20 \\
0.20 \\
0.50\end{array}$ & $8(14 \%)$ & 1.18 \\
\hline \multirow[t]{2}{*}{ Lukozi } & $\begin{array}{l}\text { Lower slopes } \\
\text { (Hortic Plaggic } \\
\text { Anthrosols } \\
\text { (Hypereutric, } \\
\text { Clayic)) }\end{array}$ & $\begin{array}{l}\text { Settlements and } \\
\text { cultivation of } \\
\text { maize, beans, } \\
\text { Irish potato, } \\
\text { wheat, and fruits, } \\
\text { terraces and } \\
\text { intensive miraba } \\
\text { farming }\end{array}$ & $\begin{array}{l}\text { Makanya } \\
\text { Kwebua } \\
\text { Hambalawe } \\
\text { Tiku } \\
\text { Kwekangaga } \\
\text { Mahokoi }\end{array}$ & $\begin{array}{l}0.20 \\
0.20 \\
0.20 \\
0.22 \\
0.28\end{array}$ & $18(32 \%)$ & 0.20 \\
\hline & $\begin{array}{l}\text { Valley bottoms } \\
\text { (Hortic Plaggic, } \\
\text { Irragric Anthrosols } \\
\text { (Hypereutric, } \\
\text { Epiclayic)) }\end{array}$ & $\begin{array}{l}\text { Intensive } \\
\text { irrigated } \\
\text { vegetable } \\
\text { cultivation } \\
\text { (cabbage, } \\
\text { carrots, } \\
\text { tomatoes, and } \\
\text { Irish potato), } \\
\text { sketchy miraba } \\
\text { farming }\end{array}$ & $\begin{array}{l}\text { Nabwa } \\
\text { Lukozi } \\
\text { Chamkwavi } \\
\text { Kwezizi }\end{array}$ & $\begin{array}{l}0.20 \\
0.33 \\
0.20 \\
0.22\end{array}$ & $24(42 \%)$ & 0.55 \\
\hline
\end{tabular}

Key: Plague frequency (PF) < 0.2 Low; > 0.3 High; Source: (Laudisoit et al., 2007)

Long term effect of tillage and soil erosion control structures including grass strips and miraba farming is among the human activities hypothesized to have significantly contributed to the development of human modified soils in the lower slopes of the studied landscapes. On the lower slopes, miraba have resulted into the development of progressive terraces promoted by tillage erosion (Kimaro et al., 2005). The thick colluvium forming at the lower part of the miraba terrace if a barrier is present is a major cause of many buried original soil surfaces observed in this 
landscape. The effect of this practice is the development of thick fertile human modified colluvial soil layers with buried original soil profile along the miraba terrace. Also long-term application of forest soils and manure in the vegetable fields cultivated intensively in the valley bottoms of the studied landscapes is a plausible explanation of the observed anthropogenic soils in the valley bottoms of the study area (Msita, 2013).

Generally speaking agricultural fields surrounded by fallow lands provide suitable sites for shelter and breeding for rodents (Mwanjabe, 1993) while plantation forest with crop farming provides both shelter and food resources (Tews et al., 2004). The grasses grown in miraba have been reported to be a hiding place for pests like rats (Msita et al., 2011). Miraba could enhance environmental conditions for rodent burrowing and shelter against predators (Brabers, 2012). As it was observed in the field rodents make routes under miraba grasses for easy engagements and for searching food and water in the lower slopes along the valley bottoms. This explains the relatively high abundance of small mammals in the Lukozi landscape.

The observed variations of flea index among anthropogenic soils and land use types could be attributed to the impact of human activities and land use management practices on flea habitats (Laudisoit et al., 2009a; Hubbart et al., 2011). It is reported in earlier studies that microclimate affects rodent fleas' abundance and varies according to land use types (Hubbart et al., 2011). In the current study, the land use types associated with anthropogenic soils in Gologolo landscape generated higher mean flea index than Lukozi landscape. Lukozi landscape is intensively cultivated through terracing and miraba farming. The lower flea index in the Lukozi landscape could be explained by the effect of tillage of land which destroys surface and subsurface microclimate (Hubbart et al., 2011) which could be disadvantageous to flea survival.

Previous studies show that flea index could be used as a proxy for plague infection risk in many areas including Tanzania (Laudisoit et al., 2007; Pham et al., 2009; Zimba et al., 2011). In this study high plague frequency was reported corresponding to the observed flea indices (Table 5). Flea species (Xenopsylla brasiliensis and Dinopsyllus lypusus) reported in this study and which make up $61 \%$ of the total collection have capacity of transmitting Yersinia pestis with different efficacy (Laudisoit, 2009). Anthropogenic soils are highly fertile soils likely to draw humans into contact with fleas infected with Yersinia pestis. This observation is worth to consider as it provide important implications for plague surveillance in relation to anthropogenic processes and land use patterns in space and time.

This study acknowledges that land use and human activities in the studied landscapes have led to pronounced development of fertile anthropogenic soils which support land use patterns which are potential habitats for rodents and fleas. The study suggests that an important interface exist between land use patterns, anthropogenic soils and plague with small mammals and fleas in the interplay. Furthermore, the study reveals that anthropogenic soils are highly fertile soils likely to draw humans into contact with fleas infected with Yersinia pestis. In this study significant number of flea species capable of transmitting Yersinia pestis was associated with land use patterns on highly fertile anthropogenic soils, suggesting that such an environment could be a potential plague risk environment, hence should be considered during plague surveillance programmes. The study provides important implications for plague surveillance in relation to anthropogenic processes and land use patterns in space and time.

\section{Acknowledgements}

This work was supported by the SUA-VLIR Own Initiative Project - 'Landscape-Ecological Clarification of Bubonic Plague Distribution and Outbreaks in the Western Usambara Mountains, Tanzania' (Acronym: LEPUS), funded by the Flemish Interuniversity Council (VLIR), Belgium. The authors greatly appreciate the cooperation of many people including farmers in the study area, staff of Lushoto District Council and Sebastian Kolowa Memorial University (SEKOMU) who in many ways facilitated the accomplishment of this work. 


\section{References}

Baize, D. (1993) Soil Science Analyses. A Guide to Current Use. John Wiley \& Sons Ltd. West Sussex. pp 192.

Bor, A. (2010) Properties of dark anthropogenic soil and influence of charcoal on crop growth in the Negev Desert (Israel). MSc Thesis, Wageningen University, The Netherlands. 70 pp.

Brabers, L. (2012) Land Characteristics, Soil Properties and Microclimate Associated with Rodent Burrows in a Selected Plague Focus, Lushoto District, Tanzania. MSc Dissertation, Katholieke Universiteit Leuven, Belgium, 85pp.

Kuo, C., Hunag, J., Shu, P., Lee, P, Kelt, D.A. \& Wang, H. (2012) Cascading effect of economic globalization on human risks of scrub typhus and tick-borne rickettsial diseases. Ecological Applications 22, 1803-1816

Davis, S., Makundi, R.H., Machang'u R.S. \& Leirs, H. (2006) Demographic and spatio-temporal variation in human plague at a persistent focus in Tanzania. Acta Tropica 100, $133-141$.

Dent, D. \& Young, A. (1981) Soil Survey and Land Evaluation. George Allen and Unwin, London, UK. pp 278.

FAO (2006) Guidelines for Soil Description. Food and Agriculture Organization, Rome. 66pp.

Glaser B (2007) Prehistorically modified soils of central Amazonia: a model for sustainable agriculture in the twenty-first century. Philosophical Transactions of the Royal Society B 362, 187-196.

Glaser, B., Haumaier, L., Guggenberger, G. \& Zech, W. (2001) The 'Terra Preta' phenomenon: a model for sustainable agriculture in the humid tropics. Naturwissenschaften 88, 37- 41

Hubbart, J.A., Jachowski, D.S. \& Eads, D.A. (2011) Seasonal and among-site variation in the occurrence and abundance of fleas on California ground squirrels (Otospermophilus beecheyi). Journal of Vector Ecology 36, 117-123.

Hubeau, M. (2010) Land use and human activity patterns in relation to the plague disease in the West Usambara Mountains, Tanzania. MSc. Dissertation, K.U.Leuven, Belgium. 102pp.

Kamugisha, M.L., Gesase, S., Minja, D., Mgema, S., Mlwilo, T.D., Mayala, B.K., Msigwa, S., Massaga, J.J. \& Lemnge, M.M. (2007) Pattern and spatial distribution of plague in Lushoto, north-eastern Tanzania. Tanzania Health Research Bulletin 9, 12-18.

Kimaro, D.N., Deckers, J.A., Poesen, J., Kilasara, M. \& Msanya, B.M. (2005) Short and medium term assessment of tillage erosion in the Uluguru Mountains, Tanzania. Journal of Soil and Tillage Research 81, 97-108

Kwan-Cheol, S., Byung-Geun, H., Yeon-Kyu, S., Chan-Won, P., Hyen-Chung, C. \& Yong, M. (2011). Taxonomical classification of Cheongweon Series distributed on broad continental alluvial plains. Korean journal of Soil Science \& Fertilizer 44, 1272-1278

Laudisoit, A. (2009) Diversity, Ecology and Status of Potential Hosts and Vectors of the Plague Bacillus Yersinia pestis. Contribution to the Plague Epidemiology in an Endemic Plague Focus: The Lushoto District, Tanzania. PhD Thesis, Universiteit Antwerpen, Belgium. 259pp.

Laudisoit, A., Leirs, H., Makundi, R.H. \& Krasnov, B. (2009a) Seasonal and habitat dependence of fleas parasitic on small mammals in Tanzania. Integrative Zoology 4, 196-212.

Laudisoit, A., Leirs, H., Makundi, R.H., Van Dongen, S., Davis, S., Neerinckx, S., Deckers, J. \& Libois, R. (2007) Plague and the human flea, Tanzania. Emerging Infectious Diseases 13, 687-693.

Laudisoit, A., Neerinckx, S., Makundi, R.H., Leirs, H. \& Krasnov, B. (2009b) Are local plague endemicity and ecological characteristics of vectors and reservoirs related? A case study in north-east Tanzania. Current Zoology 55, 199-211.

Makundi, R.H., Kilonzo, B.S. and Massawe, A.W. (2003) Interaction between rodent species in agro-forestry habitats in the western Usambara Mountains, north-eastern Tanzania, and its potential for plague transmission to humans. In: G.R. Sigleton, L.A Hinds, C.J Crebs \& D.M Pratt eds). Rats, Mice and People: Rodent Biology and Management. Australian Centre for 
International Agricultural Research, Canberra, pp. 20-24.

Makundi, R.H., Massawe, A., Mulungu, L. 2007) Reproduction and population dynamics of Mastomys natalensis Smith, 1834 in an agricultural landscape in the Western Usambara Mountains, Tanzania. Integrative Zoology 2, 233-238.

Meuser H. (2010) Anthropogenic Soils. Environmental Pollution 18, 121-193.

Moberg, J. (2000) Soil and Plant Analysis Manual. The Royal Veterinary and Agricultural University, Chemistry Department, Copenhagen, Denmark. 133pp.

Msita, H.B., Kimaro, D.N., Kihupi, N.I., Dondyene, S., Msanya, B.M., Mtakwa, P.W., Poesen, J. \& Deckers, J. (2011) Evolution of Miraba: An Indigenous Soil Erosion Control Technology in the Western Usambara Mountains, Tanzania. Paper presented to the International congress on: Integrated water-resources management in tropical and subtropical dry lands held at Mekelle, Ethiopia from 19-26 September 2011.

Msita, H.B. (2013) Insights into Indigenous Soil and Water Conservation Technologies in Western Usambara Mountains, Tanzania. PhD Thesis, Arenberg Doctoral School, Faculty of Bioscience Engineering, Ku Leuven, Belgium. 194pp.

Msita, H.B., Kimaro D.N., Deckers, J. \& Poesen, J. (2010) Identification and Assessment of Indigenous Soil Erosion Control Measures in the Usambara Mountains, Tanzania. Chapter 3 in Earl T. Nardali (Ed). No-Till Farming: Effects on Soil, Pros and Cons and Potential. Agriculture Issues and Policies Series. Nova Science Publishers Inc, New York: 49-74.

Msita, H.B., Kimaro, D.N., Mtakwa, P.W., Msanya, B.M., Mwango, S., Dondyene, S., Poesen, J. \& Deckers, J. (2012) Effectiveness of miraba an indigenous soil and water conservation measures on reducing runoff and soil loss in arable land of western Usambara Mountains. Paper presented to the EGU General Assembly 2012, in Vienna Austria, $22^{\text {nd }}-27^{\text {th }}$ April 2012.

Mwanjabe, P.S. (1993) The role of weeds on population dynamics of Mastomys natalensis in Chunya (Lake Rukwa) valley. In: Economic Importance and Control of Rodents in Tanzania, (ed.) S. Machang'u, pp. 34-42. Sokoine University of Agriculture, Morogoro.

Neerinkx, S., Peterson, A.T., Gulinck, H., Deckers, J., Kimaro, D. \& Leirs, H. (2010) Predicting potential risk areas of human plague for the Western Usambara Mountains, Lushoto District Tanzania. American Journal of Tropical Medicine and Hygiene 82, 492-500.

Pham, H.V., Dang, D.T., Minh, N.T., Nguyen, N.D. \& Nguyen, T.V. (2009) Correlates of environmental factors and human plague: an ecological study in Vietnam. International Journal of Epidemiology 38, 1634-1641.

Tews, J., Blaum, N. \& Jeltsch, F. (2004) Structural and animal species diversity in arid and semiarid savannas of the southern Kalahari. Annals of Arid Zone 42, 1-43.

WRB (2006) World Reference Base for Soil Resources. World Soil Resources Reports No 103. FAO, IUSS Working Group. Rome. 88pp.

Zimba, M., Pfukenyi, D., Loveridge, J. \& Mukaratirwa, S. (2011) Seasonal Abundance of Plague Vector Xenopsylla brasiliensis from Rodents Captured in Three Habitat Types of Periurban Suburbs of Harare, Zimbabwe. Vector-Borne and Zoonotic Diseases 11, 1187-1192. 